First Monday, Volume 1, Number 1 - 6 May 1996

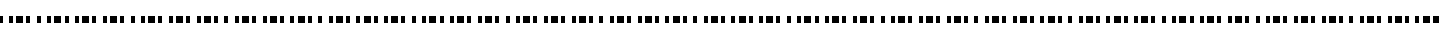

First Monday

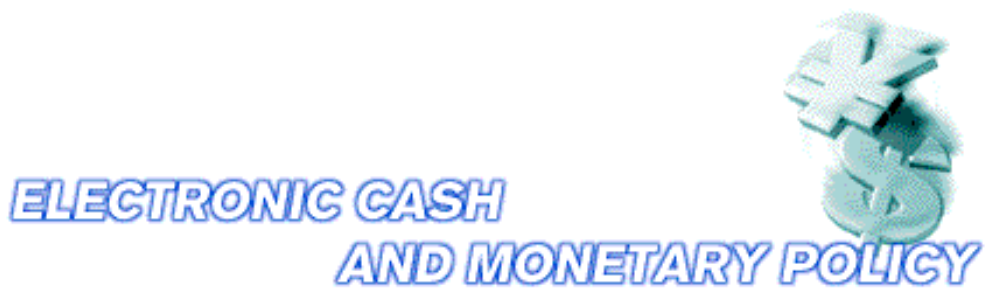

BY MARK BERNKOPF

The Two Revolutions

Is 1996 the Year of Electronic Money?

Electronic Money: Neither New nor Exotic

Central Banks and Electronic Cash

When is an Institution a Bank?

The Effects of an Electronic Currency

Privately-Issued Currencies

Contingency Planning and Maintaining Confidence

Internet Resources on Electronic Cash and Monetary Policy

\title{
The Two Revolutions
}

New payments technologies are heralding what appears to the greatest union of the disciplines of science and money since Sir Isaac Newton, Master of the Mint, unwittingly put Great Britain on the gold standard, back in 1720.

Web sites about digital cash and other electronic payment systems have been proliferating wildly. Moreover, every major newspaper, business magazine, and evening television news broadcast seems to have featured at least one story about "electronic money" or "digital cash." There are now about at least four paperback books on electronic cash, each of similar thickness, appearance, and price, for sale in North American bookstores. No doubt there are more such books on the way.

To top it all off, Nicholas Negroponte has called 1996 "the year of electronic money." Professor Negroponte and other analysts talk about a revolution transferring power from governments and central banks to investors, consumers, and entrepreneurs.

\section{Is 1996 the year of electronic money?}

Not, perhaps, for everyone. Take, for example, the country where Professor Negroponte made his declaration - France. The French experience with electronic commerce via smart cards and minitels dates to the 1980s - ancient history to most Internet users. Moreover, Japan and much of Western Europe have long used prepaid telephone cards.

In contrast, it is only now that smart cards and other implements of electronic commerce being developed for the "Anglo-Saxon" economies [1]. Aside from Danmont of Denmark and Avant of Finland, developments in electronic commerce in the non-English-speaking world have not been well reported in the English-speaking press. At the end of this article, I have listed a couple of Internet sites that shed more light on these activities.

And what of this new revolution taking power from the hands of politicians, civil servants, and central bankers, and placing it in the hands of theaverage citizen?

There are actually two electronic money revolutions underway - an electronic money revolution and an electronic cash revolution. Let me define the terms:

- "Electronic cash" is the digital replacement for banknotes and coins, in other words, electronic money for small transactions.

- "Electronic money" includes electronic cash, as well as the immense torrents of digital funds that zip through international and national payments networks [2], such as SWIFT, Fedwire

http://www.ny.frb.org/pihome/fedpoint/fed43.html, and CHIPS http://www.ny.frb.org/pihome/fedpoint/fed36.html.

The electronic cash revolution is bringing electronic money to the ordinary consumer and merchant. For the "Anglo-Saxon" economies, this revolution is only just beginning.

It is the electronic money revolution that has shifted so much economic power from the State to financial markets. This 
revolution arrived some years ago. It has already shaken the landscape, as the European Exchange-Rate Mechanism crises of 1992 and 1993 attest. Worldwide liberalization of government controls on capital outflows - combined with new telecommunications and computing technologies - have enabled huge electronic "hot money" flows to flash around the globe in search of the highest returns. Nowadays private-sector financial capital greatly outweighs central bank foreign-exchange reserves and international trade-related flows, although until a few years ago this was not the case.

\section{Electronic Money: Neither New Nor Exotic}

Electronic money is neither new nor all that exotic. According to a U. S. Treasury official [3] , Western Union made the first electronic funds transfer (EFT) in 1860, the year that Lincoln was first elected President of the United States. This EFT was made by telegraph, and was an analogue rather than digital payment, but it was an electronic payment nonetheless [4]. Moreover, the technology to support this type of EFT dates back to May 1844, when Samuel F. B. Morse first demonstrated the telegraph. Indeed, Fedwire started as a Federal Reserve telegraph system as long ago as 1918. And SWIFT and CHIPS date to the early 1970s.

Electronic money is an old concept; moreover, most money is already electronic. In the U.S. and other economies, banknotes and coins compose only a small percentage of what we conventionally define as "the money stock." Only the narrowest monetary aggregate, MO - used by few except the British - is composed chiefly of metallic and paper currency [5]. The narrowest monetary aggregate into which most conceptions of electronic cash would fall, M1, is composed of currency, traveler's checks, demand deposits, and other checkable deposits. In countries that make heavy use of checks, like the United States, banknotes and coins comprise only a minor share of M1. The broader the monetary aggregate, the smaller the share of banknotes and coins.

\section{Central Banks and Electronic Cash}

Although the electronic money revolution has made an enormous economic impact, it is the electronic cash revolution that has captured the imagination, stimulating new interest in the nature of money.

The first central banks to seriously study electronic cash have been smaller West European institutions, such as the Nederlandsche Bank and the Bank of Finland. The Dutch central bank's attention to electronic cash is largely due to the location of DigiCash and similar ventures and research centers in the Netherlands. In an interesting instance of socialism or state entrepreneurship (take your pick), the Bank of Finland actually has a corporate subsidiary, Avant Finland Ltd., developing that country's Avant cash-card system.

In contrast to the cybersavvy smaller West European central banks, the more powerful central banks, such as the Federal Reserve and the Bundesbank, have gotten a relatively late start studying the new technologies. For some time, the Bundesbank's reactions to electronic cash fell somewhere between suspicion and disdain. But this past November, it was Bundesbank President Tietmeyer who convened the Group of Ten central banks to study this issue [6]; the G-10 report should be available in a few months. Top-level American central bankers have likewise studied the issue only recently. A couple of years ago, when asked about digital cash, then-Federal Reserve Vice Chairman Alan S. Blinder replied "Digital what?", adding a few moments later, "It's literally at the thinking stage [ㄱ]."

In the United States, the Domestic and International Monetary Policy Subcommittee of the House of Representatives Banking Committee has been holding occasional hearings on "The Future of Money."

http://www.house.gov/castle/banking/money.htm These hearings feature electronic entrepreneurs, bank executives; university professors; managers of urban mass-transit authorities using "closed" stored value systems; Federal law-enforcement officials, the U.S. Treasury executives, and a Vice Chairman of the Federal Reserve Board.

Aside from the Director of the Mint, who would welcome the opportunity to issue commemorative cash cards, the U.S. Government has adopted a wait-and-see attitude toward electronic cash. This results from a reluctance to inhibit private-sector development of new payment techniques and technologies.

The leading common technical standard for cash cards, EMV, was developed by the private sector, specifically Europay, MasterCard International, and Visa International. The private sector is also developing security standards on its own, even challenging hackers to break their codes for a reward.

Had the U.S. Government wanted to dictate standards, it would have been in a good position. The U.S. Department of Agriculture is exploring the digitization of "Food Stamp" coupon for indigent American families. The Department of Defense's worldwide network of base facilities, including commissaries and PX's, also could have given the U.S. Government substantial influence over standards.

In recent years, the Working Group on Payment Systems of the European Union has presented studies on new payments technologies to the Council of the European Monetary Institute (EMI)

http://www.kub.nl:2080/library/instructie/eue/24monet.htm, the embryonic European Central Bank. In its May 1994 study on prepaid cards, the Working Group on Payment Systems called for limiting the issue of electronic cash to "credit institutions," in other words, banks. This approach would seem instinctive to any central banker, because banks are already subject to supervision. However, because of the ease with which nonbanks can now issue money, Dutch central bankers now believe that all issuers of electronic cash should be regulated, bank and nonbank alike.

When is an Institution a Bank? When is a Prepaid Card Balance E-Cash? 
In early April 1996, the Board of Governors of the Federal Reserve System issued its proposed modernization of Regulation $\mathrm{E}$, the main regulation governing electronic financial transactions in the United States. The new "Reg E" would waive paper receipts for small transactions, and for the first time establishes rules for stored value cards. There have also been several bills introduced into Congress that substantially rewrite the Electronic Funds Transfer Act, the legislation that governs "Reg E." Minneapolis attorney Chris Sand berg discusses the legal issues affecting digital cash in InfoNation magazine. http://www.info-nation.com/cashlaw.html

Even aside from the inevitable modernization of the laws and regulations governing "e-cash, [8]" long-established notion are being turned on their head.

For example, what is a bank? Is it any institution that lends money? That accepts deposits? That lends money and accepts deposits simultaneously? The commonly accepted definition of bank is fast becoming outmoded. Many have observed that it would not take much for Microsoft or AT\&T and other large software and telecommunications firms to expand into the banking business.

What is electronic cash? When does the balance on a multipurpose card become electronic cash? When does stored value qualify for deposit insurance? When must stored value card issuers maintain reserve requirements? These questions raise issues that transcend the academic.

What is and what is not electronic cash - or any other form of money - is not a simple yes-or-no question, but rather a matter of degree. Money is usually a liability of its issuer, effectively an interest-free loan to the issuer from its holder. Nonetheless, precisely because money is a matter of degree, the definition of money is rather ambiguous.

Let us assume that all the photocopiers in a university library require the use of a university-issued prepaid card. We would consider this card arrangement a "closed system."

What if vending machines at the university library are retrofitted to accept our photocopier card? Our closed system has gotten a tad more open.

Now assume that all the vending machines and photocopiers throughout the campus accept the library photocopier card.

What to obtain a copy of your transcript? What if the university registrar, and every university department and instrumentality on campus accepts photocopier cards?

Now, what if the five colleges and universities in the metropolitan area accept each other's photocopier cards? What if, soon thereafter, off-campus laundromats, restaurants, and newsstands at each of these institutions accepts photocopier cards?

Is the balance on the photocopier card cash? Well, the single-purpose card has unquestionably become a multipurpose card, a relatively open closed system. But it is not cash yet, because it is not universally accepted.

Now assume that all the photocopiers and vending machines and off-campus businesses suddenly accept VisaCash, MasterCard Cash, and Mondex cards. These would be open systems, presuming that every local establishment has the equipment to process electronic-cash transactions. The cash cards, if issued by a bank, would be protected by deposit insurance. Moreover, it is likely that the Federal Reserve would require some sort of reserves to back the electronic cash.

Would banks be required to issue electronic cash with the same reserves as those required for savings and checking accounts? Today, for most banks, the reserve ratio is a mere three percent. In other words, for every dollar of electronic cash created by a bank, there need be only three cents in bank reserves.

Today, under current U.S. law, a nonbank institution is free to issue multipurpose cards without any reserve requirement. However, these nonbank cash cards are not be protected by Federal deposit insurance. Hence, Dutch central bankers recognize that all electronic cash issuers, bank and nonbank alike, must be monitored by the monetary and banking authorities.

But the existence of multipurpose cards make the issue quite difficult to sort out. When hotels and gasoline stations accept frequent-flier miles, those miles become a quasi-currency.

Several weeks ago, a U.S. Government prosecutor asked a Federal court to confiscate the frequent-flier miles of a captured marijuana smuggler. His home, financial savings, and other property had already been seized by Federal authorities. The smuggler had accumulated enough mileage to qualify for three round-trip visits from the United States to the Bahamas.

\section{The Effects of An Electronic Currency}

In Western Europe, new developments in monetary technology share the headlines with attempts to establish Economic and Monetary Union (EMU). EMU now seems an uncertain proposition. Among the signatories to the Maastricht Treaty, only Luxembourg now meets the convergence criteria for Economic and Monetary Union (EMU). The political momentum for a single European currency so visible immediately after the signing of the Maastricht Treaty has dissipated. Although Tim Jones, CEO of Mondex says that his Mondex card would be an ideal vehicle to test electronic Euros, others believe 
that electronic cash, far from aiding the Euro, could deliver its coup de grace.

Giles Keating, chief international economist at CS First Boston in London, believes that electronic money might derail Economic and Monetary Union (EMU) in Europe. In a guest column in the November 2, 1995 Financial Times, Keating reminds readers that many of the electronic cash technologies accommodate several currencies simultaneously on a home computer or a cash card. Moreover, the new technologies dramatically reduce foreign-exchange transactions costs. A resident of a country with a chronically weak currency could easily shift his savings into stronger ones. Indeed, there could easily be a massive flight of electronic financial assets from weak currencies to stronger ones, effectively driving the weaker, less significant currency out of existence - a sort of Gresham's law in reverse. Ultimately, those European governments with terminally weak currencies would be able to compel the use of their currencies for "legal tender transactions" only, such as income taxes and driver's license fees.

If the electronic cash became widespread, then for every dollar of banknotes or coins replaced by private-sector electronic cash, the Federal Reserve System, through its open-market operations trading desk in New York, would be obliged to sell one dollar of U.S. Government securities. Moreover, the Federal Reserve, and ultimately the U.S. Treasury, would lose the interest income that it would have earned otherwise []].

Note that the electronic cash would not be a private currency. Instead, to be accepted by the U.S. banking clearing and settlements system, it would have to be denominated in the official U.S. unit of account, the dollar.

The widespread adoption of electronic cash would deprive Federal authorities of a substantial amount of "seignorage," the margin between the face value of currency issued, and the costs of issuing that currency. In 1994, the Federal Reserve turned about $\$ 20$ billion in seignorage over to the Treasury.

\section{Privately-Issued Currencies}

In his essay "Digital Cash and Monetary Freedom," Jon W. Matonis, an executive with the digital certificate developer VeriSign, Inc., points out that the new technology offers the possibility of privately-issued currencies. Matonis takes his inspiration from the late Professor Friedrich von Hayek, whose essay "The Denationalisation of Money" includes the following quotation:

Money does not have to be created legal tender by government: like law, language and morals it can emerge spontaneously. Such private money has often been preferred to government money, but government has usually soon suppressed it.

This is a theme that can be traced as far back as the 1851 writings of Herbert Spencer, the father of "social Darwinism" and a strong opponent of government intervention in the economy.

Matonis is quite correct that the new technology makes easier the use of multiple private currencies. There is no reason why Intuit, Meca or Microsoft cannot develop an intelligent agent to optimize the value of the digital currencies stored in one's hard-disk drive or PC card. Such an agent would resemble a foreign-exchange or corporate treasury trading desk. Moreover, any Internauts are quite enthusiastic about the idea of "currency competition."

But why would anyone want to hold a private currency when there are so many strong national currencies about? This is not merely a matter of "free banking," but of the introduction of who new units of account. Despite advanced technology, dealing with multiple currencies seems unnecessarily confusing. The whole idea of private currencies seems preposterous. Yet Friedrich von Hayek was no crank, nor are his followers. In many respects von Hayek was ahead of his time. At a time when the economic establishment - including Republican and Conservative leaders - accepted the Phillips curve analysis that a little inflation was a small price to pay for more employment, it was von Hayek who condemned inflation because it distorts prices, which serve as essential information signals in a market economy.

Why use Microsoft dollars or Virgin Atlantic sterling when there already is the Deutsche mark? If you reply that the D-mark may not be around too much longer, then why not use the Swiss franc, the New Zealand dollar, or the Japanese yen? I do not know whether Microsoft will be around in a century to redeem Bill dollars, but I am relatively certain - the USSR, Yugoslavia and Czechoslovakia notwithstanding - that the United States will be around.

Why should a private-sector currency be any more stable than a national one? This seems more an article of theology than of economic logic.

Assume that, for the past century, we all had lived in a world of private currencies. What if, one day while cleaning out the attic, you suddenly happened upon Grandpa's stash of Eastern Airlines dollars? Fond memories of Eddie Rickenbacker and Frank Borman may remain, but Eastern Airlines doesn't. Gramps' Eastern dollars would be good for wallpaper and birdcages, but not much more.

There is no statute prohibiting any U.S. citizen from issuing his own currency. According to Sir Samuel Brittan of the Financial Times, this is also more or less the case in the United Kingdom. If, as Professor von Hayek alleged, privately-issued money can arise as spontaneously as law, language and morals, why is it not here? In his essay on private currencies, Hayek blamed capital controls for the failure of private currencies to develop. Yet capital controls are largely gone, and there are still no private currencies.

There are two answers. First, there really is no demand for any private-sector form of money other than brand-name 
traveler's checks and your own demand-deposit and money-market-fund checks.

Second, there actually is an almost continuous history of private currency ventures, in the United States and elsewhere. In the old American West, when the mining companies were low on cash, they would sometimes pay the employees in company scrip, which was accepted at the local company-owned store. More recently, in the 1960's and 1970's, American supermarket shoppers would accumulate "S\&H Green Stamps," which were redeemable in special S\&H retail outlets.

But there is no compelling reason for citizens and businessmen to accept private scrip. If banks refuse to accept private currencies, and the country's clearing and settlement systems refuse to accept private currencies, then why should anyone else?

Perhaps there might someday be demand for such a currency in a land where hyperinflation is rampant, and local currency has lost all meaning. But even here, I would think that dollarization would be a simpler, easier solution. Would a private currency ever acquire as much trust as the dollar or the Deutsche mark or the Swiss franc or the yen? I strongly doubt it.

\section{Contingency Planning and Maintaining Confidence}

This past autumn, National Westminster Bank PLC encountered a problem with its credit-card authorization network. NatWest blamed the equipment's supplier, British Telecommunications PLC. BT blamed NatWest for overburdening the computer system.

NatWest and BT are also collaborators on Mondex. Suppose that Mondex' security were breached, and NatWest and BT engaged in another round of fingerpointing?

At the end of the day, money is about confidence. Public recriminations can easily be as devastating to confidence in an e-cash product as an actual breach of security. The development of contingency plans and crisis-management skills do not receive much public attention. Perhaps, to some extent, effective contingency planning requires some discretion. Nonetheless, this seems an issue that merits attention from central banks and other banking authorities.

Internet Resources on Electronic Cash and Monetary Policy

Hearings on "The Future of Money" by the Subcommittee on Domestic and International Monetary Policy, Committee on Banking and Financial Services, United States House of Representatives, 104th Congress, Washington, D. C. URL:

http://www.house.gov/castle/banking/money.htm

To read about U.S. Treasury and Federal Reserve System policy toward electronic cash, please consult the October 11, 1995 testimony of Comptroller of the Currency Eugene A. Ludwig and then-Federal Reserve Board Vice Chairman Alan S. Blinder.

To obtain hard copies of the Subcommittee "Future of Money" hearing transcripts for July 25 and October 11, 1995 , telephone +1-202-226-0473. A paper transcript of the February 27, 1996 hearing was not yet available when this paper was written.

"The Electronic Purse," by John Wenninger and David Laster, in Current Issues in Economics and Finance, April 1995, Federal Reserve Bank of New York, New York. URL: http://www.ny.frb.org/rmaghome/curr_iss/ci1-1.html To obtain a free copy of this article via snail mail, telephone the New York Fed's Public Information Department at +1-212-720-6134. Laster and Wenninger serve in the Payment System Studies Staff of the New York Fed.

"Policy Issues Raised by Electronic Money," by David Laster and John Wenninger, Federal Reserve Bank of New York. URL: http://www.ctr.columbia.edu/citi/emon.html This paper was presented at the Conference on Digital Cash and Electronic Money, Columbia Institute for Tele-Information, Columbia Business School, Columbia University, New York, 21 April 1995.

"Electronic money in a race with Emu," by Giles Keating, Head Economist of CS First Boston in London, Financial Times, November 2, 1995, p. 15. http://icg.stwing.upenn.edu/hypermail/cis899/0123.html

"Showdown over E-cash," by Howard Anderson, Upside, January 1996.

http://www.upside.com/resource/print/9601/ecash.html Anderson is Managing Director of The Yankee Group, a Boston consultancy. He is also a founder of Battery Venture, a Boston venture capital firm. He has a reputation as something of a contrarian when viewing long-term technology trends.

"Electronic Cash: two sides to the story," by Dimitrios Kyriakou, Institute for Prospective Technological Studies, Seville, Spain. http://www.jrc.es/reports/vol00/dkelecca.htm

"So much for the cashless society," The Economist, 26 November 1994, p. 21.

http://www.ios.com/ Iroth/clips/emoney.html This was the first article to outline the challenges that electronic cash would face central bankers and other policymakers.

"Digital Cash \& Monetary Freedom," by Jon W. Matonis, April 1995.

http://www.isoc.org/in95prc/HMP/PAPER/136/html/paper.html 
http://www.interfinance.com/digicash.html

http://www.publitronix.com/digital cash/home.html

http://www.eff.org/pub/Privacy/Anonymity/Digital_money/matonis_on_dig_cash.paper

Matonis is a longtime libertarian, currency and futures trader, founder of the Institute for Monetary Freedom, and executive with VeriSign Inc. of Mountain View, California, a developer of digital-certificate products and services.

"Electronic Commerce and the Banking Industry: The Requirement and Opportunities for New Payment Systems Using the Internet," by Andreas Crede, University of Sussex, Science Policy Research Unit, in Journal of Computer-Mediated Communication, Special Issue on Electronic Commerce, December 1995.

http://www.usc.edu/dept/annenberg/vol1/issue3/crede.html

Smart Cards and Systems Newsletter

http://www.cardshow.com/scs-secure/i10/country_news.html

Discusses several cash and multipurpose card projects.

A Panorama of the Electronic Purse Around The World

http://www.cardshow.com/applications/EP/contents.html

The above two sites are presented by the Smart Card Cyber Show.

The Author

Mark Bernkopf has served at the Open Market Operations Department of the Federal Reserve Bank of New York and in the research unit of the White House Office of Communications. He is now an independent consultant in Arlington, Virginia, just outside Washington, D.C. Toward the end of last year, Bernkopf prepared two in-depth studies on electronic cash for overseas clients. He can be contacted by e-mail at markb@erols.com and by snail mail at: 4001 North 9 th Street, Suite 1110, Arlington, Virginia 22203-1964 USA

Notes

1. By "Anglo-Saxon," I mean the U.K., U.S., Canada, Australia, New Zealand, and Ireland.

2. Fedwire is the wire transfer facility operated by the Federal Reserve System for the purchase and sale of excess reserves among American banks. CHIPS, the Clearing House Interbank Payment System, is a privately-owned network for transfers in the millions or billions of dollars by banks and large corporations in the U. S. SWIFT, the Society for Worldwide Interbank Financial Telecommunication, is an international payments network headquartered in Brussels. Technically, SWIFT is a messaging system rather than a payments system, but the distinction need not concern us.

3. Gary R. Garner, Financial Management Service, speech at "Stored Value Cards" conference, organized by the Center for Business Intelligence, Washington, D. C. September 1995.

4. In this age of digitized payments, the words "digital" and "electronic" can be used more or less interchangeably.

5. MO is pronounced "em naught."

6. There are actually eleven member economies in the Group of Ten.

7. See BusinessWeek, June 12, 1995, "E-cash could transfer the world's financial life,"

http://www.kgtv.com/newslink/NLwed/BWst orya.html

8. ecash(tm) (without a hyphen) is trademarked by DigiCash. However, "e-cash" (with a hyphen) is generic shorthand for electronic cash. This suggests that DigiCash will have an interesting time fighting to retain its trademark in the years ahead, as "e-cash" becomes a household word. One solution to DigiCash's troubles would be the popularization of the Japanglish term "d-cash" as the everyday parlance for digital cash. Presumably we need not fear anyone confusing d-cash with the D-mark.

9. The Federal Reserve generally turns interest income over to the Treasury.

Copyright (C) 1996, First Monday 